\section{Geografia turyzmu w Uniwersytecie \\ Marii Curie-Sklodowskiej w Lublinie Zakład Geografii Regionalnej i Turyzmu}

W Uniwersytecie Marii Curie-Skłodowskiej w Lublinie inicjatorem problematyki badawczej z zakresu geografii turyzmu był prof. Tadeusz Wilgat. Mimo że nie doszło do powołania specjalizacji $\mathrm{z}$ tego zakresu, jednak wiele problemów typowych znajdujemy $w$ pracach publikowanych i archiwalnych, a także w pracach magisterskich, powstałych w zakładach: Hydrografii, Ochrony Środowiska, Kartografii i Geografii Regionalnej.

Aktualnie problematyka badawcza i dydaktyczna w zakresie geografii turyzmu koncentruje się w kierowanym przez dr hab. Andrzeja Świecę Zakładzie Geografii Regionalnej. W Zakładzie zatrudnieni są adiunkci - dr Teresa Brzezińska-Wójcik, dr Waldemar Kociuba, dr Ewa Skowronek, asystenci - mgr Renata Krukowska, mgr Andrzej Tucki; doktorantka - mgr Małgorzata Buczek. W latach 2000-2007 na ogólną liczbę 73 konferencji, w których aktywnie uczestniczyli pracownicy Zakładu Geografii Regionalnej - 30\% nawiązywało do geografii turyzmu. Byliśmy organizatorami czterech konferencji o tematyce turystycznej. W liczbie około 180 publikacji z okresu 2000-2007 znalazło się prawie 25\% o tematyce geografii turyzmu. Finalizowane są trzy rozprawy doktorskie: Uwarunkowania rozwoju $i$ zróżnicowanie funkcji turystycznej Pojezierza Łęczyńsko-Wtodawskiego, Potencjat turystyczny regionu lubelskiego $i$ możliwości jego wykorzystania i Funkcjonowanie turystyki uzdrowiskowej na obszarze transgranicznym Karpat w okresie transformacji ustrojowych.

Od roku akademickiego 2003/2004 w ramach specjalności geografii fizycznej funkcjonuje grupa specjalizacyjna - geografii turyzmu (seminarium dr hab. Andrzeja Świecy). Od 1 października 2008 r. na Wydziale Biologii i Nauk o Ziemi UMCS został uruchomiony nowy kierunek studiów „turystyka i rekreacja". Rozwój badań i dydaktyki z zakresu turyzmu w Zakładzie Geografii Regionalnej był podstawą do wniosku o zmianę nazwy na Zakład Geografii Regionalnej i Turyzmu.

\section{Geography of tourism at Maria Curie-Skłodowska University in Lublin \\ Department of Regional Geography and Tourism}

The pioneer of research in the field of tourism geography at Maria Curie-Sklodowska University in Lublin was Prof. Tadeusz Wilgat. Even though the specialisation group in tourism geography was not then established, many of the issues related to this field can be found in publications, archives and master's theses written in the departments of Hydrography, Environmental Conservation, Cartography and Regional Geography.

Currently, the research and teaching activity in the field of tourism geography is concentrated within the Department of Regional Geography headed by Prof. Andrzej Swieca. In the department Dr Teresa Brzezińska-Wójcik, Dr Waldemar Kociuba and Dr Ewa Skowronek are employed as senior lecturers; Renata Krukowska, MSc; Andrzej Tucki, MSc - as assistant lecturer; while the department has one $\mathrm{PhD}$ student - Małgorzata Buczek, MSc. During 2000 2007, members of the Department of Regional Geography actively participated in 73 conferences, $30 \%$ of which were related to the geography of tourism. The department itself has organized four conferences on this topic. Among 180 publications issued in 2000-2007, 25\% were connected to tourism geography. Currently, three doctoral dissertations are being finalised: Conditions for the development and diversity of tourist functions in the Łeczna-Wtodawa lake district, the tourist potential of the Lublin region and opportunities for its realisation, and the functioning of spa tourism in the crossborder areas of the Carpathians at the time of political transformation.

Since the academic year 2003-2004, the specialization group in tourism geography has functioned as a part of the specialization in physical geography (seminar led by Prof. Andrzej Świeca). Since October 1st, 2008, a new course Tourism and Recreation - will be offered by the Faculty of Biology and Earth Sciences of Maria Curie-Sklodowska University. The development of research and teaching programmes in the field of the geography of tourism in the Department of Regional Geography has served as a basis for a formal application to change the department's name to the Department of Regional Geography and Tourism. 